\title{
The Anatomy of Asian Palm Civet (Paradoxurus hermaphroditus) Brain in Timor Island
}

\author{
Filphin Adolfin Amalo', Yulfia Nellymalik Selan', Antin Yeftanti Nugrahening Widi², \\ Andry Ndula Rimu ${ }^{3}$
}

'Anatomy, Physiology, Pharmacology, and Biochemistry Department of Faculty of Veterinary Medicine, Nusa Cendana University

${ }^{2}$ Clinics, Reproduction, Pathology, and Animal Nutrition Department of Faculty of Veterinary Medicine, Nusa Cendana University

3 Student of Faculty of Veterinary Medicine, Nusa Cendana University

*Correspondence: drh.filphin.amalo@gmail.com

\begin{abstract}
Asian palm civet (Paradoxurus hermaphroditus) is native to some Asian regions, include Indonesia. Despite its wide spreading in those areas, study in regards to its anatomy is very few. This study is aimed to unveil the anatomy of Asian plam civet brain in Timor island. This study was performed in three Asian palm civets. The palm civets were anesthesized and humanely euthanazied using perfusion technique, and macroscopically observed for their brains anatomy. Results showed Asian palm civet consisted of three main parts which were cerebrum, cerebellum, and brain stem. Compared to brain of dog, sulci and gyri of the Asian palm civet is simpler, with paraflocculus lobes were merely located in dorsal and ventral parts of the brain. However, the vermis was more similar to dogs, and more developed compare to Reusettussp (Javanese codot). This suggests that the anatomical difference is a result of the different behavior, which are nocturnal animal and live on trees.
\end{abstract}

Key words:brain, cerebrum, cerebellum, brain stem, Paradoxurus hermaphroditus

Copyright (c) 2019 JRVI. All rights reserved.

\section{Introduction}

Asian palm civet (Paradoxurus hermaphroditus) has become one of Indonesian biodiversity. IUCN categorizes it as least concern species (Duckworth et al, 2008). Lately, this wild animal has turned into pet animal, without any considerations from the owner that it is a reservoir which transmits rabies, the zoonotic disease. Few rabies cases in monkeys and civets had been reported before (Sidhartaet al., 1996cited in Sarosaet al., 2000). Based on the brain anatomy similarity to dogs, Rousettussp may become a natural reservoir of rabies (Sari et al., 2014).

Brain is a vital organ of living creatures as it serves as the center of body coordination. Brain is the place where any activities of living organism are regulated; include responses to any stimulation from surrounding environment (Ma'ruf, 2001). Brain shows its uniqueness in its regulatory mechanism towards body, from receiving information from sensory organs, combine them, and sending responses in the form of action by the body. Another important function of 
brain is the memory center (Guyton, 1983 cited in Gunawan, 2001).The capacity of brain function in some manner is related to its anatomy.

This study is aimed to unveil the anatomy of Asian palm civet brain macroscopically. By doing so, this may give the latest information in regards to the topic, and may become a reference for further studies.

\section{Materials and Methods}

Three 16-18 grams of Asian palm civet were taken from East Central Timor District in East Nusa Tenggara Province, Indonesia. Deep anesthesia, perfusion and removebrain from craniumwere applied to the civets in order to obtain brain. Macroscopical observation was performed to the three brain samples.

\section{Results and Discussion}

\section{Lateral view of Asian palm civet brain}

Lateral view of Asian palm civet brain shows three main parts, which were cerebrum, cerebellum, and brain stem (Figure 1).

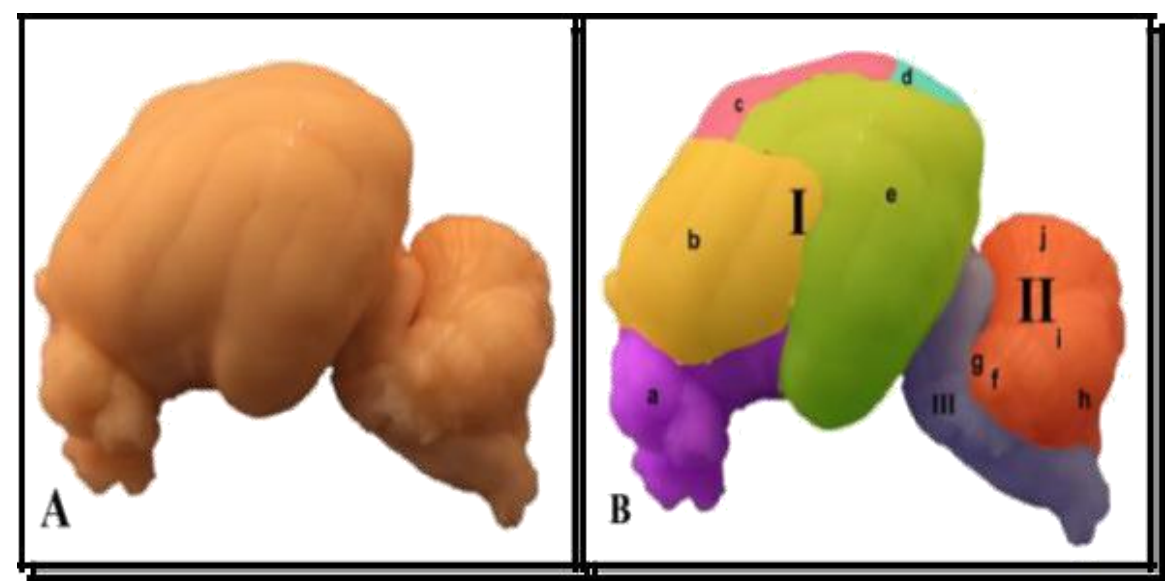

Figure 1. (A) Lateral view of Asian palm civet (Paradoxurus hermaphroditus) brain, (B) schematic picture of (A); (I) cerebrum, (II) cerebellum, (III) brain stem, (a) olfactory bulb, (b) frontal lobe, (c) parietal lobe, (d) occipital lobe, (e) temporal lobe, (f) paraflocculus lobe, (g) flocculus lobe, (h) simplex lobe, (i) asiform lobe, (j) vermis.

Cerebrum was divided intoa pair of hemispheres which were separated by longitudinal fissure. Olfactory bulb was located at the anterior of cerebrum, whereas the posterior was separated by transverse fissure from cerebellum. Cerebrum consisted of four lobes; they are frontal, parietal, occipital, and temporal lobes. Frontal lobe situated in the anterior part of the brain, meanwhile parietal lobe located at the caudal part of frontal lobe. Occipital lobe sited at the caudal part of parietal lobe, and temporal lobe was found at the lateral side of frontal lobe (Figure 1). Lateral side of the vermiswas the place where ansiform lobe, simplex lobe, paraflocculus lobe, and flocculus lobe can be found. Each ansiform lobe located on the right and left sides of the cerebellum, whereas the caudal part of this lobe was simplex lobe. At the lateral side of asiform lobe can be found flocculus lobe, meanwhile the caudal part of this lobe was paraflocculus lobe. Ventral and dorsal lobes were located inside the paraflocculus lobe. This is similar to dogs(Sari etal., 2014), however different from Rousettussp which does not have paraflocculus lobe.Paraflocculus lobes in monkeys are considerately broad, whereas in aves, is merely in ventral praflocculus lobe (Nieuwenhugset al., 2014). Paraflocculus lobe's 
functions are balancing center, also coordinating and receiving stimuli from vestibular (Macrini, 2006), in addition to increasing intelegence(Nieuwenhugset al., 2014).

\section{Dorsal view of Asian palm civet brain}

Gyri and sulci are commonly found in cerebral hemisphere surface (Akers danDenbow, 2008). The shape of Asian palm civet cerebral sulci and gyri were simpler compare to dog, due to more curved gyri and deeper sulci in the dog brain. However, sulci of Asian palm civet brain is more developed compare to Rousetusspwhich merely a line (Sari et al., 2014). Gyri of the Asian palm civet brain were marginal, ectomarginal, suprasylvian, and ectosylviangyrus. Marginal gyri were located at the right and left sides of longitudinal fissure, whereas ectomarginalgyrus was found in the cranial side of ectomarginal sulcus. Suprasylviangyrus was laid at the lateral side of marginal sulcus, while ectosylviangyruswas situated at the caudal side of ectosylvian sulcus. Sulci of the Asian palm civet brain were marginal, ectomarginal, suprasylvian, ectosylvian, cruciate, and rhinal sulcus. Marginal sulcus was located at the lateral side of marginal gyrus, while ectomarginal sulcus was positioned at the ventral side of ectomarginalgyrus. Suprasylvian sulcus was found at the cranial side of suprasylviangyrus, whereas ectosylvian sulcus was situated at the caudal side of ectosylviangyrus. Cruciate sulcus was laid at the lateral side of longitudinal fissure, and rhinal sulcus located at the ventral side of the cerebrum where which separated cerebrum from olfactory bulb (Fig. 2A3).

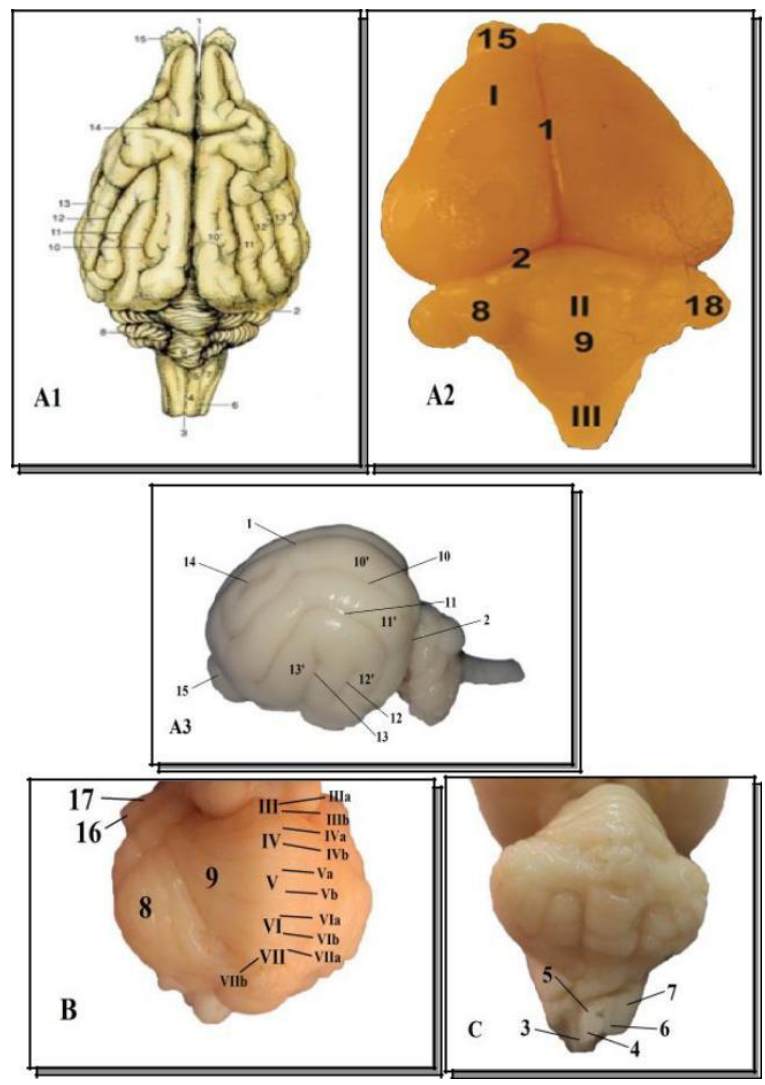

Figure 2.(A1) Dog brain (Dyce et al, 2010), (A2) Rousetusspbrain(Sari et al., 2014), (A3) Asian palm civet brain, (A) cerebrum, (B) cerebellum, (C) brain stem. (1) ongitudinal fissure I, (2) transversal fissure, (3) dorso-medial sulcus, (4) tractusgracilis, (5) nucleus gracilis, (6) tractuscuneatus, (7) nucleus cuneatus, (8) cerebellar hemisphere, (9) cerebellivermis, (10) marginal sulcus, (10') marginal gyrus, (11) ectomarginal sulcus, (11') ectomarginalgyrus, (12) supracylvian sulcus, (12') supracylviangyrus, (13) ectocylvian sulcus, (13') ectocylviangyrus, (14) cruciate sulcus, (15) olfactory bulb, (16) paraflocculus lobe, (17) flocculus lobe 
According to Miller (1969) cit. Sari et al. 2014 and Dyce et al,.(2010), dog has anterior and posterior sulci and gyri of rhinal sulcus, marginal sulci and gyri which consists of marginal, ectomarginal, and post marginal. Lateral side of dog brainhasectosylvian sulcus, also suprasylvian sulci which comprised of anterior, posterior, and medial part. The more developed sulci and gyrifound in an animal, the more neuron located in the cortex cerebri, thus the more intelligent an animal is (Kardong, 2012). This means that intelligence is influenced by the brain size, both absolute and relative, also cortex of the brain (Roth danDicke, 2005).

Vermis of the Asian palm civet cerebellum was found in the medial part of cerebellum. This vermis was similar to vermis of dogs, and more developed compare to Reusettussp.This owe to nocturnal activity of Asian palm civet as well as their behavior to live on the tree, since cerebellum commonly organizes somatic-motoric activity, also regulate muscle, body balance and posture(Strata, 2011; Fletcher, 2006). Vermis of the Asian palm civet cerebellum was divided in the same way as in mice, which consisted of ten lobes. Mice vermis lobes are IV $b$, V a, V b, VI a, VI b, VI c, VII a, VII b, VIII a, VIII b, IX a, dan IX b lobes (Byanet et al., 2013). Lobes that were identified in Asian palm civet cerebellum were la, Ib, II a, II b, III a, III b, IV a, IV b, V a, V b, VI a, VI b VII a, VII b, VIII a, VIII b, IXa, IXb, XadanXb lobes. Lobila,lb, Ila,Ilb, VIIla,VIIIb, IXa,IXb, XaandXbwere seen at the saggital cut of the cerebellum. The anterior side of vermis was the place where lobilll a dan III b were found. Towards caudal direction of these lobi were lobilV a dan IV b, Va and Vb, VI a danVb, also VII a and VII b respectively (Fig. 2B).

Nucleuses that were found in Asian palm civet brain were nucleus gracilli and nucleus cuneatus, whereas the tractus were tractusgracilis and tractuscuneatus. Nucleus gracillis was located at the dorsal part of brain stem. Tractus gracillis was situated at the caudal of the nucleus gracillis, while at the lateral side of this tractus was tractuscuneatus. Lateral side of tractusgracillis was dorsomedial sulcus (Fig. 2C).

\section{Ventral view of Asian palm civet brain}

Ventral view of Asian palm civet brain showed olfactory bulb at the anterior part of the brain, and olfactory medial stria at the caudal side of olfactory bulb, while olfactory tractus was at the lateral side of olfactory medial stria, with optic chiasm, mammillary body infundibulum, and interpendicular fossa were located at the caudal side of olfactory tractus. Rhinal sulcus was placed between cerebellum and olfactory bulb.At the lateral side of mammillary body there was tuber cinereum. Cerebral peduncles was situated at the lateral side of interpendicular fossa, while at the caudal part, there was pons. Lateral side of medulla oblongata was occupied by trapezoid body, whereas the caudal ventral was pyramid and ventro-medial fissure respectively (Fig. 3).

The other part of ventral view of Asian palm civet brain displayed the similar feature as seen in Reusettussp (Sari et al.,2014), which consisted of twelve pairs of cranial nerves. Olfactory nerve was found at the anterior part, followed by optical nerve at its caudal part. Occulomotor nerve was found at the lateral side of mammillary body and interpendicular fossa. Trochlear nerve was located at the caudal side of pons, while at its lateral side was vestibulothrochlear nerve. Towards caudal direction of of cerebral peduncles there were trigeminal nerve and facial nerve respectively. At the ventral part of medulla oblongata there was abducens nerve, while at the lateral side was glossopharyngeal nerve. In the caudal direction of glossopharyngeal nerve there were vagus nerve, accessory nerve, and hypoglossal nerve respectively (Fig. 3). 


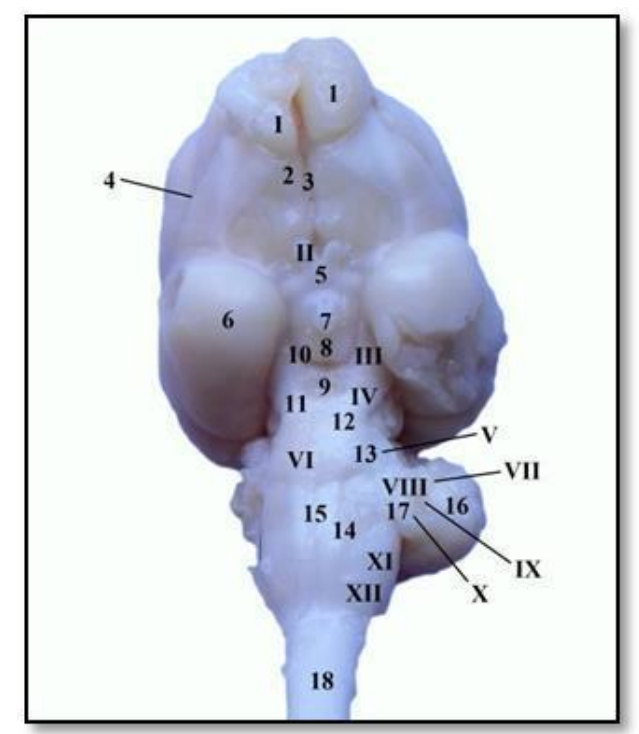

Figure 3.Ventral view of Asian palm civet brain.(1) olfactory bulb, (2) olfactory tractus, (3) olfactory medial stria,(5) optic chiasm, (6) piriform lobe, (7) infundibulum, (8) mammillary body, (9) interpencular fossa, (10) tuber cinereum, (11) cerebral peduncle, (12) pons, (13) trapezoid body, (14)pyramid, (15) ventro-medial fissure, (16) paraflocculus lobes, (17) flocculus, medula oblongata, (18)cranialis nerve, (I) olfactory nerve, (II) opticus nerve, (III) occulomotor nerve, (IV) trochlearis nerve, (V) trigeminus nerve, (VI) abducens nerve, (VII) facialis nerve, (VIII) vestibulocochlear nerve, (IX) glossopharyngeal nerve, $(X)$ vagus nerve, $(X I)$ accessory nerve, (XII) hypoglossal nerve.

\section{Sagittal view of Asian palm civet brain}

Sagittal view of Asian palm civet brain exhibited olfactory bulb at the posterior part of cerebrum, while corpus calosumfibre was located at the dorsal side of olfactory bulb. Towards caudal direction of corpus callosum fibre were corpus callosum genu and splenic sulcus respectively. At the dorsal side of splenic sulcus, there was fornix. In the caudal direction of fornix there were interventricular foramen and thalamus, while the caudal side of thalamus there was mecenchepalicaquaduct. Ventral side of fornix was the place of optic chiasm, whereas caudal side of optic chiasm was splenium. At the anterior side of medulla oblongata there was pons, while at the dorsal side, postoriolateral fissure, which was located next to cerebellum. At cerebellivermis were seen lingual, central lobe, ascendens lobe, culmen, declive, uvula, and nodules (Fig. 4).

Medial cut of Asian palm civet brain revealed corpus callosum and fornix, which interconnected cerebral hemisphere and thalamus. Corpus callosum was at the top of the lateral ventricle and base of cerebral hemisphere. Lateral ventricle was located at the right and left of cerebral hemisphere, and connected to ventricle III through interventricular foramen. Some portion of ventricle III was attached to hypophysis infundibulum, whereas ventricle IV was found between cerebellum and upper part of pons. 


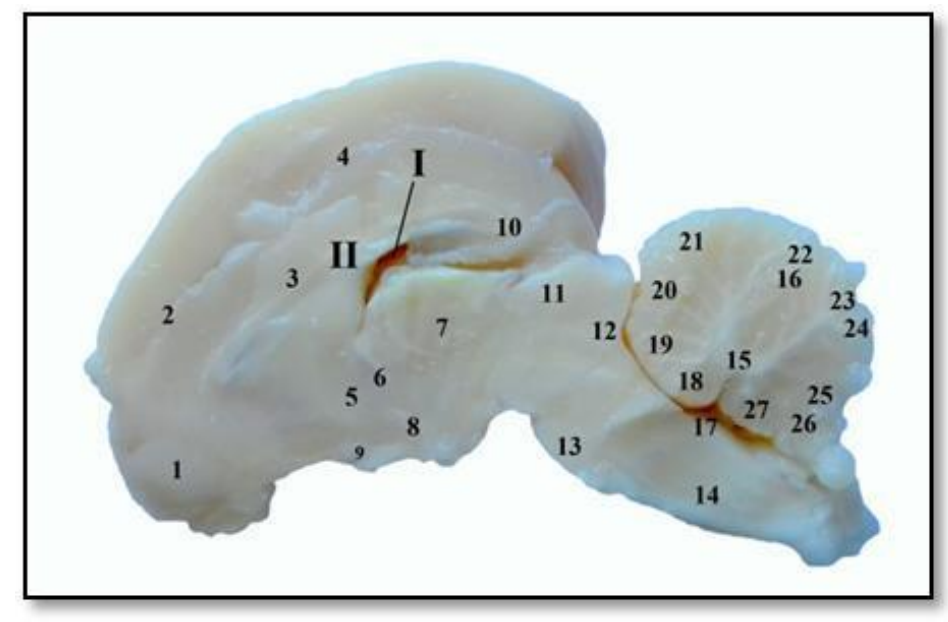

Figure 4.Sagittal view of Asian palm civet brain.(I) lateral ventricle (II) corpus callosum (1) olfactory bulb, (2) corpus callosumfibre, (3)corpus callosumgenu, (4)splenic sulcus, (5) fornix, (6) interventricular foramen, (7) talamus, (8) third ventricle, (9) optic chiasm, (10) splenium, (11) mesencephalontectum, (12) mesencephalicaquaduct, (13)pons, (14)medulla oblogata, (15) corpus medula, (16) prime fissure, (17) posterolateral fissure, (18) lingula, (19) centralis lobe, (20) ascendens lobe, (21) culmen, (22) declive, (23) folium, (24) tuber, (25)pyramid, (26) uvula, (27) nodules.

\section{Conclusion}

In conclusion, Asian palm civet (Paradoxurus hermaphroditus) brain consisted of three main parts, which are cerebrum, cerebellum, and barin stem. Sulci anggyri of this animal brain are simpler compare to sulci and gyri of dogs, however more developed than Reusettus $s p$. This indicates the higher intelligence of Asian palm civet compare to Reusettus sp. Vermis of Asian palm civet brain is more similar to dog, however more developed than Reusettus sp., which may relate to its nocturnal activity and its life on the tree.

\section{Acknowledgment}

The author would like to thank the Faculty of Veterinary Medicine, Nusa Cendana University for giving permission to use laboratory facilities available in Department of Anatomy, Physiology, Pharmacology, and Biochemistry.

\section{Refferences}

Akers, MR. and Denbow, MD. 2008. Anatomy and Physiology of Domestic Animal. Edisi pertama. USA.

Byanet, O., Samuel, OA., Barth, OI. and Jonathan, NA. 2013. Macroscopic organization of the cerebellum of the African Giant Pouched rat (Cricetomys gambianus Waterhouse, 1840). Veterinarski Arhiv 83: 695-707.

Cliquet, F. and Meyer, EP. 2004. Rabies and Rabies Related Viruses: A Modern Perspective On An Ancient Disease. Rev. Sci. Tech. Off. Int. Epiz 23(2): 625 - 642. 
Duckworth, JW., Widmann, P,,Custodio, C., Gonzales, JC., Jennings, A. and Veron, G. 2008. Paradoxurus hermaphroditus. IUCN Red List of Threatened Species.Version 2010.4. International Union for Conservation of Nature.

Dyce, KM., Sack, WO. and Wensing, CJG. 2010. Textbook of Veterinary Anatomy, 4 Edition. Saunders, London. cit.

Sari, KM., Khomariyah, S., Arofah, N.,Wardhani, WS. and Pangestningsih, TW., 2014. Studi Anatomi Otak Codot (Rousettus sp) Sebagai Satwa Liar Resevior Alami Penyakit Rabies, Jurnal Sain Veteriner 32(2): 153-161.

Fletcher, TF. 2006. Brain Gross Anatomy From The Lab Manual For CVM 6120 In: Veterinary Neurology, Supported by University of Minnesota, College of Veterinary Medicine. pp. $1-25$.

Guyton, AC. 1983. Buku Teks Fisiologi Kedokteran. Bagian 2. Edisi 5. EGC Penerbit Buku Kedokteran. Jakarta. cit. Gunawan, R. 2001. Studi Kasus Histopatologi Otak Kucing yang di Nekropsi di Laboratorium Patologi Fakultas Kedokteran Hewan-IPB Periode 1999-2000. Skripsi. Institut Pertanian Bogor. Bogor.

Kardong, KV. 2012. Comparative anatomy, function, evolution. Vertebrates. McGraw Hill Company, USA.

Ma'ruf, UA. 2001. Studi Histopatologi Susunan Syaraf Pusat Sapi yang Berasal dari Wilayah Bogor dan Bandung. Skripsi. Institut Pertanian Bogor. Bogor.

Macrini, TE. 2006. The evolution of endocranial space in mammals and non-mammalian cyndonts. Dissertation. The University Of Texas at austin. USA.

Miller, ME. 1969. Anatomy of the Dog. W. B. Saunders Company, Philadelphia, USA. cit. Sari. K. M., Khomariyah, S., Arofah, N., Wardhani, W. S. dan Pangestningsih, T. W., 2014, Studi Anatomi Otak Kodot (Rousettus sp) Sebagai Satwa Liar Resevior Alami Penyakit Rabies. Jurnal Sain Veteriner. 32(2): 153161.

Nieuwenhugs R., Donkelaar HJT., Micholson, C. 2014. The Central Nervous System of Vertebrates. Ebook.

Roth, G. and Dicke, U. 2005. Evolution of the brain and intelligence. Trends in Cognitive Science. 9:250-251.

Sari, KM., Khomariyah, S., Arofah, N.,Wardhani, WS. and Pangestningsih, TW. 2014. Studi Anatomi Otak Codot (Rousettus sp) Sebagai Satwa Liar Resevior Alami Penyakit Rabies. Jurnal Sain Veteriner. 32(2): 153-161.

Sidharta, T., Sarosa, A, and Ronohardjo, P. 1996. Tinjauan Hasil-hasil Penelitian Penyakit Rabies di Balai Penelitian Veteriner Bogor. cit. Sarosa, A., Adjid, R. M. A.,Sidharta, T. G. dan Jalaludin. 2000. Studi Penyakit Rabies di Daerah Endemik: Prevalensi Infeksi Virus Rabies Pada Anjing, Kucing, dan Tikus di Kodya Padang, Sumatra Barat'. Seminar Nasional Peternakan dan Veteriner. 561-567’.

Strata, P., Scelfo, B., Sacchetti, B. 2011. Involvement of Cerebellum in Emotional Behavior. Physiology. Res. 60 (Suppl. 1), 39-48. 